\title{
Health Workers on the Frontline Struggle for Health as a Social Common
}

\author{
Baba Aye ${ }^{1}$ \\ Published online: 10 November 2020 \\ (c) Society for International Development 2020
}

\begin{abstract}
Through the lens of health workers' concerns, the article interrogates the impact of the neoliberal turn of the 1980s on the loss of the ideal and pursuit of health as a social common. It highlights the Great Recession as a confirmation of the failure of the neoliberal project but notes that this the project continues with even greater frenzy. Capturing the dynamics which inhibit the World Health Organization, it calls for mass mobilization to reclaim health as a social common.
\end{abstract}

Keywords Neoliberalism $\cdot$ Marketization $\cdot \mathrm{WHO} \cdot$ Ama Ata Declaration $\cdot$ Ubuntu

\section{Health Workers and COVID-19}

Health workers have been the first line of humankind's defence against the rampaging incursion of the microbial world, in the shape of SARS-CoV-2. They have received accolades from peoples and governments alike. In many European cities, people would come out on their balconies at a designated time every evening to shout in honour of health and social care workers. Governments as well, joined this chorus, without government officials batting an eye.

Many questions were not considered or were left unanswered as the waves of applaud came. Why were health and social care workers saddled with so much work such that many were running insane shift periods? Why was there a global shortage of personal protective equipment (PPE) for so long? How seriously were decision-makers taking the important need to safeguard the health of those taking care of our health in this pandemic?

Some of these questions have been raised in several ways in the literature in this turbulent year. This tends to be as part of attempts to understand why the pandemic happened and how can a similar situation be avoided in the future. Finding answers for these questions requires our grasping the root of the problem. It is the primacy of for-profit interests in health

Baba Aye

baba.aye@world-psi.org

1 Public Services International, Ferney-Voltaire Cedex, France which undermine the provision of health as the fundamental human right and social common which it is meant to be.

Health, including that of the health and social worker has become a commodity. Tons of applauses without systemic change, ushering in a post-neoliberal world would be empty. Crises like the present pandemic present opportunities for structural change. Health workers are on the frontline delivering much needed care across the world. They are also on the frontline of struggle to bring about such systemic change.

This article contextualizes the problem by putting neoliberal health reforms in perspective. It then looks at efforts of health workers roles in the current period, despite daunting challenges and tries to understand why the best intentions of the World Health Organization might not be enough to ensure the realization of its mandate. It then concludes with a return to a fundamental point made in the Alma Ata Declaration ${ }^{1}$ - a pressing need for a new global social compact, for health as a common to become reality.

\section{Quicksand of Neoliberal Health Reforms}

'Since the 1970s, neoliberal health and social welfare policies around the world shifted resources from the public to the private sector'. This has had adverse effect 'on the wellbeing of health and human service care workers' as well as patients (Abramovitz and Zelnick 2010: 97). Health workers have faced increasing work intensity and less control on the job, leaving them 'emotionally and physically depleted'.

\footnotetext{
${ }^{1}$ https://www.who.int/publications/almaata_declaration_en.pdf.
} 
High levels of on-the-job stress and burnout became a regular feature of their lives.

This ideologically-driven decline of public expenditure in healthcare; privatization of healthcare services, and; dismantling of public health infrastructures (Navarro 2008: 153), went on overdrive from the end of the 1980s as the fall of the Soviet Empire paved way for capitalist triumphalism of the neoliberal order, best captured with Fukuyama's vision of the 'end of history' at the time (Fukuyama 1989). Radical changes were made in the public sector as New Public Management (NPM) became the norm in Western countries, rolling back the welfare state of the post-World War II order.

The rights-based essence of public service delivery was eroded, in fact, if not always in words. Along with privatization, cost cutting measures became engrained in the public sector in imitation of the supposedly inherent efficiency of the private sector. Healthcare delivery was not spared. On the contrary health, as one of the fastest growing sectors of the economy (in an age where the value of everything was considered only as its worth in dollars or euros), was a major target of the neoliberal anti-public sector reforms. This was pushed through with a flurry of 'health reforms' which entailed marketization of healthcare delivery.

The presence and influence of for-profit interests in health and social care grew exponentially. Global healthcare companies, big pharmaceuticals and insurance firms grew in numbers, wealth, and influence. With the use of outsourcing, contracting out and diverse forms of public-private partnerships, they latched onto public health systems, milking it of resources. An increasing number of workers delivering health and social care in public health systems became fixedterm contract staff.

As the welfare state was being rolled back in the West, the developmental-interventionist state which had been able to prioritize healthcare delivery was also being smashed in the developing world. International financial institutions played a key role in this. Many countries were embroiled in debts after a series of economic setbacks in the 1970s from the oil crisis to the Volcker shock. As they turned to the International Monetary Fund and World Bank in the 1980s, they were slammed with structural adjustment programmes.

And while IMF loans are officially meant to help member countries tackle balance of payment problems, the conditionalities that went with these included setting caps on public sector employment.

These ceilings have been identified as key impediments to hiring or retaining health sector workers, and are linked to medical "brain drain" as health workers migrate in search of better employment opportunities (Kentikelenis 2017: 299)

The Great Recession at the end of the 2000s demonstrated the failure of neoliberalism in practice. But to reassert the resultant dent of neoliberal hegemony, governments stuck even more religiously with the ideology of this failed god. Instead of less, we had more neoliberalization of health and care as well as social life as a whole.

Fiscal discipline was pushed through with austerity measures, as governments and international finance institutions did all they could to make working-class people bear the cost of economic recovery, while bailing out corporations whose profit maximization led to the crisis. The public wage bill was either cut or had caps put on it in 130 out of 187 by 2015 (Ortiz et al. 2016).

Health and social workers were particularly hard hit. For example, a 2015 Guardian survey showed that NHS staff were the 'most stressed public sector workers' in Britain. ${ }^{2}$ This is not surprising, as they are 'under-resourced and definitely understaffed' as one of the respondents of the survey said.

And on top of that, they are underpaid. Their wages were frozen for 7 years and after that, wage increases were capped at $1 \%$ for another year until 2018. The case in Greece was no better. The salaries of healthcare workers were cut twice in 2010 . First by $12 \%$ in January and then by another $8 \%$ in June (Economou et al. 2014).

In a world where profit had become god, with productivity and 'efficiency' its trusted servants, increases in health sector wages were considered at best as a cost disease (Baumol and Bowen 1993). But, as the pandemic shows quite clearly, reducing the value of human labour to the economic logic of productivity does great injustice to workers concerned and our collective humanity.

To roll back the commodification of health and devaluing of the labour of healthcare requires holistic root and branch radical reforms aimed at enthroning universal public healthcare.

\section{Health Workers and Ubuntu ('I am Because You Are')}

The pandemic met a global health workforce that was understaffed, underpaid, under-resourced and overstressed. But health workers rose to perform what was close to miracles, putting their lives at risk to save lives. With their lived experiences at a critical hour for humankind, they demonstrated and emphasized the social commons that health in its essence is.

From the doctors and scientists in China who dared local party officials to get information out on the new coronavirus,

\footnotetext{
${ }^{2}$ https://www.theguardian.com/healthcare-network/2015/jun/12/nhsstaff-most-stressed-public-sector-workers-survey-finds. Accessed 28 October 2020.
} 
to the Indian nurses and doctors who wore diapers to save personal protective equipment which was in short supply ${ }^{3}$ health workers demonstrated courage and self-sacrifice. Marketization of healthcare prepared the ground for hospitals that felt like war zones as surges spiked in different countries. ${ }^{4}$ Like the Polish cavalry charge at Krojanty in 1939, ill-equipped though they have been, healthcare workers bought humankind time as much as they could, in the face of the rampaging SARS-CoV-2.

The task was made the more difficult by a number of interrelated causes within the neoliberal paradigm which had informed health reforms over the decades.

The privatization of healthcare was one of such key determinants. Analysis covering 147 countries for example, that preponderance of private provision of healthcare as well as cross-cutting policies such as 'reduction in the number of hospital beds per 1000 people' result in significantly higher 'rates of COVID-19 prevalence and mortality across countries' by up to $4.3 \%$ and $4.9 \%$ respectively (Assa and Calderon 2020: 17).

This analysis was concerned more with the direct impact of privatization and cuts in public hospitals beds on the higher risks of COVID-19 prevalence and mortality. We need to also consider the indirect impact.

The plummeting of public health investment in Europe since 2008 contributed to increasing pre-existing health states which predisposed persons to being infected. For example, public health spending in England fell by $£ 870 \mathrm{~m}$ since 2014. This might have "caused 130,000 deaths and a rise in chronic conditions like diabetes, that incidentally also make you more likely to die from COVID-19' (Mackenzie 2020: 42).

As several former and serving United Nations Special Rapporteurs point out, the pandemic exposes the catastrophic impact of privatizing vital services such as water and sanitation, and health. ${ }^{5}$ The social and economic determinants of health are as much part of the fabric of our collective humanity which should not be left to the determination of market forces. The consequences of the reign of such corporations over our social commons, as the pandemic shows, could be disastrous.

The global shortage of PPE was a stark case of an emergency within the global health emergency. But it did not just happen. It speaks to how global supply chains have evolved

\footnotetext{
3 https://timesofindia.indiatimes.com/city/bengaluru/bengaluru-tosave-ppe-doctors-nurses-wear-diapers-avoid-drinking-water/artic leshow/75019145.cms. Accessed 29 October 2020.

${ }^{4}$ https://www.nytimes.com/2020/03/19/us/hospitals-coronaviru s-ppe-shortage.html. Accessed 29 October 2020.

5 https://www.theguardian.com/society/2020/oct/19/covid-19-expos ed-catastrophic-impact-privatising-vital-services. Accessed 29 October 2020 .
}

to best serve profit maximization as the first law of social production, which explains why governments across the world were not prepared in several other ways, when the pandemic broke out.

One of the lessons from the 2002-2004 SARS outbreak was that ensuring the health of health workers and preparing for surge capacity must be accorded priority, to avert the worst impact of epidemic outbreaks. And several simulation exercises which should have informed governments and the international community to look beyond the logic of on-time production to ensure consummation of these priorities. These include NHS England's Exercise Cygnus which showed lack of crisis preparedness of the British government for a flu pandemic. ${ }^{6}$ The WHO's R\&D Blueprint for Action to Prevent Epidemics' Disease X in 2018 should likewise have also served as caution for stockpiling PPE. But, with for-profit interests upping policy formulation that puts people first, why keep capital expended on such essential equipment tied down before a pandemic's Pandora escaped from its box?

This demonstration of 'savage capitalism', as Noam Chomsky ${ }^{7}$ puts it, was not just passive in terms of not having needed medical devices ready, it was also active. As Chomsky informs, drawing lessons from the Ebola outbreak in 2014, the Obama administration entered a contract to make 'high-quality, low-cost ventilators' available for such eventualities as now befall the world was sabotaged by a corporation which bought the original smaller company contracted, because 'it was competing with their own expensive ventilators'.

But while neoliberal hegemony continues to hold sway, pushing the maxim of there being no such thing as social commons, the pandemic forced the hands of several governments to take radical and far-reaching actions to safeguard the social commons, in the early months of the pandemic. These included the requisitioning of private hospitals, conversion of factories to produce needed medical devices, supplies and PPE.

This was however not with the spirit of ubuntu which health workers demonstrated. These temporary measures did not necessarily amount to taking the private health facilities into public hands or their "nationalization" ${ }^{8}$ as sensationalized in the press. There is a pressing need to go beyond the limited and feeble demonstrations of government's turn to

\footnotetext{
${ }^{6}$ https://www.theguardian.com/world/2020/may/07/what-was-exerc ise-cygnus-and-what-did-it-find. Accessed 29 October 2020.

7 https://jacobinmag.com/2020/4/noam-chomsky-coronavirus-pande mic-trump. Accessed 29 October 2020.

8 https://www.businessinsider.fr/us/coronavirus-spain-nationalisesprivate-hospitals-emergency-covid-19-lockdown-2020-3. Accessed
} 29 October 2020 
seeming consideration of health as a social common, and only so during emergencies like the COVID-19 pandemic.

\section{Whither the World Health Organization?}

Founded in 1948 as part of the multilateral United Nations system, the World Health Organization has a mandate 'to act as the directing and co-ordinating authority on international health work' towards achieving the objective of 'the attainment by all peoples of the highest possible level of health' (WHO 1995).

From the 1980s when the World Bank delved into lending to the health sector on a large scale, this leading role of the organization has been challenged (Clift 2013). The rise of diverse global health initiatives over the last few decades have accelerated this whittling of WHO's real powers. And relatedly, its increasing reliance on voluntary contributions, including-indeed increasingly more-from philantrocapitalist foundations.

This has severe long-term implications. These 'nonstate actors' influence has helped to consolidate the hold of private interests on the health system internationally and in countries across the world leading to; undermining of accountability mechanisms, institutional hybridization, weakening of 'public sector and government responsibility' for health and social care, fostering opacity and the illusion of a redistribution of wealth by the elite. ${ }^{9}$

The multi-stakeholderism promoted by philantrocapitalism, and perennial failure of governments to live up to their financial and other commitments whittle the capacity of WHO to serve in reclaiming health as a social common. It is against this background that such laudable resolutions that would have helped safeguard the health and well-being of health workers such as the 2017 Working for Health: FiveYear Plan for Health Employment and Inclusive Economic Growth have failed to translate into concrete steps on the ground.

The politics of the COVID-19 global response echoes the need for reinstatement of the WHO's leading role in international health. Global health initiatives such as GAVI and CEPI occupy more or less equal place in the Access to COVID-19 Tools Accelerator (ACT-Accelerator), while WHO cannot arrest the unfurling of vaccine nationalism.

\footnotetext{
9 https://www.nicolettadentico.eu/wp-content/uploads/2019/06/Phila ntrocapitalism_DiscussionPaper_10-2018-2.pdf. Accessed 29 October 2020.
}

\section{Conclusion}

The neoliberal turn of the 1980s represents a loss of the trajectory of social progress towards health as a social common. Commodification and marketization of health which started with the incursion of international financial institutions at that period reflected a change in the global social and economic order to one of the most naked forms of capitalism. This laid the basis for nightmare which health workers have faced in the pandemic-overworked, underpaid and ill-protected.

Health works realize the need to change this situation. Public Services International, the global trade union federation which brings together thirty million workers across the world, about half of which are in the health and social sector has called for 'rapid changes in policies....that put people and planet over profit'. ${ }^{10}$

This requires advocacy and lobbying of the WHO and countries. But even much more it requires monumental social mobilization to restructure the world as we know it, with public health for all at the heart of such this. We must remember that it took 'the combination of militant social movements and structural changes in the economy' to give birth to 'the rise of the welfare state' (Abramovitz and Zelnick 2010: 98).

It is also important to note that the Alma Ata Declaration recognized the fundamental importance of economic and social development (at the time envisioned as the "New International Economic Order') for the fullest attainment of health for all and reduction of health inequities to become reality.

'The post-COVID-19 age will usher in a new era of social and political relations' (Horton 2020: 127). But the nature of this is not pre-defined. It could be more of the same as the post-Great Recession age has been. We must contest it and fight for it to be an age of health as a social common-a post-neoliberal age.

\section{References}

Abramovitz, Mimi, and Jennifer Zelnick. 2010. Double jeopardy: The impact of neoliberalism on care workers in the United States and South Africa. International Journal of Health Services 40 (1): 97-117.

Assa, Jacob, and Cecilia Calderon. 2020. Privatization and Pandemic: A Cross-Country Analysis of COVID-19 Rates and Health-Care Financing Structures. https://www.researchgate.net/publicatio n/341766609_Privatization_and_Pandemic_A_Cross-Count

\footnotetext{
10 https://publicservices.international/resources/news/covid-19-emerg ency--psi-priorities-and-perspectives?id=10694\&lang=en. Accessed 29 October 2020
} 
ry_Analysis_of_COVID-19_Rates_and_Health-Care_Finan cing_Structures. Accessed 28 October 2020.

Baumol, William J., and William G. Bowen. 1993. Performing Arts, The Economic Dilemma: a study of problems common to theater, opera, music, and dance. Cambridge, MA: M.I.T. Press.

Clift, Charles. 2013. The Role of the World Health Organization in the International System. Working Group on Governance I Paper 1, Chatham House.

Economou, Charalampous, Daphne Kaitelidou, Alexander Kentikelenis, Aris Sissouras, and Anna Maresso. 2014. The impact of the financial crisis on the health system and health in Greece. Report for European Observatory on Health Systems and Policies. http:// www.euro.who.int/_data/assets/pdf_file/0007/266380/Theimpact-of-the-financial-crisis-on-the-health-system-and-healt h-in-Greece.pdf. Accessed 28 October 2020.

Fukuyama, Francis. 1989. The End of History? The National Interest 16: 3-18.

Horton, Richard. 2020. The COVID-19 Catastrophe, What's Gone Wrong and How to Stop It Happening Again. Cambridge: Polity Press.

Kentikelenis, Alexander E. 2017. Structural adjustment and health: a conceptual framework and evidence on pathways. Social Science and Medicine 187: 296-305.
Mackenzie, Deborah. 2020. COVID-19 the pandemic that should have never happened and how to stop the next one. London: The Bridge Street Press.

Navarro, Vincente. 2008. Neoliberalism and its consequences: The world health situation since Alma Ata. Global Social Policy 8 (2): 152-155.

Ortiz, Isabel, Matthew Cummins, Jeronim Capaldo, and Kalaivani Karunanethy. 2016. The decade of adjustment: A review of austerity trends 2010-2020 in 187 countries. ESS Working paper No. 53, The South Centre Initiative for Policy Dialogue, Colombia University, International Labour Office.

World Health Organization (WHO). 1995. Constitution of the world health organization. Geneva: WHO.

Publisher's Note Springer Nature remains neutral with regard to jurisdictional claims in published maps and institutional affiliations. 